\title{
Article
}

\section{Why destination visitor travel planning falls between the cracks}

\author{
Guiver, Jo W and Stanford, Davina \\ Available at http://clok.uclan.ac.uk/13550/ \\ Guiver, Jo W ORCID: 0000-0001-6126-3662 and Stanford, Davina (2014) Why \\ destination visitor travel planning falls between the cracks. Journal of \\ Destination Marketing \& Management, 3 (3). pp. 140-151. ISSN 2212-571X
}

It is advisable to refer to the publisher's version if you intend to cite from the work. http://dx.doi.org/10.1016/j.jdmm.2013.11.005

For more information about UCLan's research in this area go to

http://www.uclan.ac.uk/researchgroups/ and search for <name of research Group>.

For information about Research generally at UCLan please go to http://www.uclan.ac.uk/research/

All outputs in CLoK are protected by Intellectual Property Rights law, including Copyright law. Copyright, IPR and Moral Rights for the works on this site are retained by the individual authors and/or other copyright owners. Terms and conditions for use of this material are defined in the policies page.

\section{CLoK}

Central Lancashire online Knowledge www.clok.uclan.ac.uk

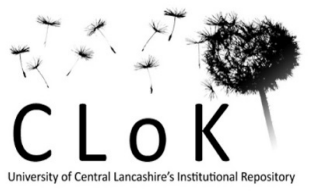




\section{Why destination visitor travel planning falls between the cracks}

\section{Introduction}

Travel is the glue of tourism; it brings the customers from their home area to the destination area and connects their accommodation with attractions and activities within the area. Travelling in the area will generate many of the impressions which lead tourists to return, or not, and to recommend the area to others, or not. Yet the responsibility for planning such a vital element in the quality of visitor experience is often divided between multiple agencies without the resources or common purpose to ensure a quality product.

Although the majority (75\%) of tourism's greenhouse gas emissions are from transport, these are predominantly from travel to and from the destination area. However, within areas, travel accounts for a high proportion of visitor emissions (approximately a third in small destination areas), local pollution and degrading of the visitor environment. It is also an aspect of tourism which can be influenced by local destination management, provision and policy. Within destination areas, visitor travel planning offers opportunities not only to reduce local and global impacts, but to improve the tourist offer, open areas to new markets and generate extra spending within the area. Yet, most attempts to offer alternative forms of travel to visitors are unco-ordinated, patchy and underfunded.

This paper results from our own puzzlement about why what seems a simple way of reducing the environmental impact of visitor travel is rarely implemented. It brings together evidence from close contact with a number of destination areas through research and consultancy projects in sustainable tourism, discussions with destination managers, examination of reports and other "grey literature", promotional materials as well as published research to help answer the question. It concludes that an "easy win" for more sustainable tourism, improving the quality of the experience and helping local tourism providers, is highly improbable without an agency charged with taking a strategic view and empowered to deliver it. However, isolated examples of successful sustainable tourism transport initiatives exist and the elements contributing to their success are explored.

The literature review draws on a range of previous research about the impacts of tourism travel on global and local environments and the role of visitor travel planning in reducing these impacts. It discusses why strategies for utility travel planning are not appropriate for leisure travel. The benefits of visitor travel planning to different stakeholders are outlined before exploring theories and evidence for the dynamics of tourist destination management. After a brief explanation about the origin and evidence for the paper and its scope, the instruments of visitor travel planning provision and promotion are explained with numerous examples from the UK rural destinations. The successes and limitations of different organisational models are described.

The discussion explores why visitor travel planning has not been introduced in many tourist areas and why it is unlikely to develop or be maintained in such a volatile context. It is followed by a short résumé of the paper's thesis that, while visitor travel planning offers considerable advantages to most actors within a tourist destination, it is unlikely to thrive.

\section{Literature review}

\subsection{Tourism and environment}

In May 2013 the concentrations of CO2 equivalents in the atmosphere rose to over $400 \mathrm{ppm}$ for the first time in human history (Carrington, (2013) and Intergovernmental Panel on Climate Change, 
(2013)). The last time the earth experienced these concentrations, several million years ago, sea levels were up to $40 \mathrm{~m}$ higher than they are today (Carrington, 2013). The rise in temperature caused by the increase in $\mathrm{CO} 2$ and other greenhouse gases has already triggered a number of "feedback reactions" such as the release of $\mathrm{CO} 2$ from warming oceans, and the melting of permafrost and polar ice caps, which increases the absorption of heat (Intergovernmental Panel on Climate Change, (2007) and Moritz et al., 2002). Although governmental and inter-governmental action has been painfully slow, it is clear that every industry, including tourism, will need to reduce its greenhouse emissions in the near future.

It is estimated that tourism contributes approximately $5 \%$ of global greenhouse emissions, with $75 \%$ of those from transport, the majority (40\%) from aviation, followed by car travel (32\%) (United Nations World Tourist Organisation, 2007). Travel to and from destinations, rather than travel within the destination area accounts for most of these emissions. Yet within destination areas, local travel appears to offer one of the easiest targets for reducing greenhouse gas emissions, as well as potential for improving the local tourism offering. For example, visitor travel accounted for $32.7 \%$ of the total visitor carbon count within the English Lake District, only surpassed by accommodation, food and drink (Cumbria County Council, Small World Consulting Ltd., 2010). Studies in Majorca and Cyprus also found that about one-third of the visitor carbon count within the destination area comes from local travel (Dick Sisman \& Associates, 2007). Larger areas may have a higher proportion of their emissions from internal travel, particularly where this includes air and sea travel. For example, it is estimated that $56.3 \%$ of the emissions relating to visitors in Queensland are from travel, with flights and trips by boat accounting for $82.5 \%$ of total travel emissions (Hoque et al., 2010). However, assessing the true contribution of visitor travel can present a number of data problems (Peeters \& Schouten, 2006).

In most destination areas, the majority of transport emissions are from car use (e.g. 97.4\% (Small World Consulting Ltd., 2010), 77\% in Cornwall (Small World Consulting Ltd, 2012). Car use is also the source of local environmental impacts such as pollution, noise, danger and congestion, all of which lessen the attractiveness of an area for tourists and residents (Beunen et al., 2008, Connell and Page, 2008, Kendal et al., 2011 and Sharpley and Sharpley, 1999).

This influx of car-borne visitors threatens many of the special qualities that draw both residents and visitors to the two National Parks in the first place. Air and water pollution levels rise; habitats and landscape character are threatened by vehicle encroachment; tranquillity is broken by traffic noise; and the wider impacts of transport emissions and their contribution to climate change are already being seen in changing ecosystems, migration patterns and other critical aspects of species and habitat survival (South Downs National Park Authority and New Forest National Park Authority, 2012).

It is now widely recognised that all forms of transport, especially the private car, have a major impact on the environment in terms of visual and noise pollution, visual impact, emissions of $\mathrm{CO} 2$ and other pollutants that contribute to global warming, congestion and road traffic injury to both humans and wildlife (Speakman and Transport for Leisure Ltd, 2008a).

A further reason for providing for car-free travel within a destination area is to influence the mode of arrival. Domestic and medium to short haul tourists use cars both for travel within the holiday area and to/from it. These trips contribute to the carbon count of the destination. Removing the need for a vehicle at the destination opens the possibility of more sustainable travel to it and is seen as a necessary step to encourage car owners to arrive by more sustainable modes (Kirkbride, (2011) and South Downs National Park Authority \& New Forest National Park Authority, (2012)). 


\subsection{Utility and leisure travel planning}

The environmental impact of car use for utility trips has been addressed in many areas by travel planning and there is an extensive literature about the subject (see Ampt, (2003), Jones and Sloman, (2003) and Rye, 2002). It focuses on reducing car use for journeys (especially those with low car occupancy) where there are practical alternatives.

However, leisure travel differs significantly from utility travel (Page, 1999) and so requires different strategies from those used for more routine journeys. The main differences are:

minimising the cost and/or time of journeys may be inappropriate, because of their intrinsic value, being part of the experience rather than just instrumental in getting between places. This provides opportunities to add value through novelty (e.g. steam trains, open-top buses), interpretation or other forms of engagement with the locality. Lew and McKercher (2006) differentiate between outcome-oriented tourists, who aim to minimise transit time and process-oriented tourists who perceive travel time of value, attributing the quality to the tourist, rather than the specific triptraveller context. Robbins and Dickinson $(2008$, p. 109) however, contend that trips to attractions are predominantly derived from demand, however pleasurable the journey experience.

being less routine, leisure travel is often in unfamiliar territory (Jafari, 1987) with little opportunity for trialling different routes, modes, timing of trips.

the destination is often discretionary and can be influenced by considerations of the "bundle" of mode, activity and destination (March \& Woodside, 2005) such as: drive to the coast, bus ride to attraction, bike ride along the canal or walk in local woods. Changing destinations can be important for reducing the distance travelled and increasing the potential to use a more sustainable mode.

Other common differences are that leisure travel is frequently undertaken in groups, leading to higher car occupancy than for utility travel (Small World Consulting Ltd $(2012$, p. 31) and that some leisure activities, especially in rural areas, require substantial amounts of equipment lending themselves to private car travel (Dickinson and Dickinson, 2006 and Dickinson and Dickinson, 2006). Tourism's emphasis on being welcoming also excludes many of the measures to discourage car use advocated in utility travel planning (Guiver, 2011a and Speakman and Transport for Leisure Ltd, (2008a)). Businesses reliant on car-borne visitors can also be reluctant to introduce measures which they fear might discourage those visitors or reduce their spending (Speakman and Transport for Leisure Ltd, (2008a) and Stanford, 2013).

\subsection{Visitor travel planning}

Visitor travel planning seeks to reduce the local and global effects of visitors' travel within a tourist area, encouraging people to reduce their car use by switching to other modes or reducing the length and frequency of car journeys. The use of alternative methods of travel is promoted by making them cheaper, easier to use or by enhancing the experience.

Car use can be reduced within destination areas without reducing the number of visitors by: 
decreasing the number of trips (e.g. making it possible to spend all day at one or a close group of destinations)

reducing the distance travelled (encouraging people to visit attractions closer to their accommodation or use accommodation closer to the attractions they want to visit)

transferring to another mode such as public transport, walking, cycling (see Warren, 2010).

Visitor travel planning endeavours to encourage these actions, through provision of more choice of active travel and public transport alternatives, facilitating more sustainable, but attractive, ways of travelling around the area, enhancing their intrinsic value, promotion of alternative modes and closer destinations.

\subsection{The benefits of visitor travel planning}

Visitor travel planning has potential to benefit visitors, tourism providers, local residents and the environment. Where there has been strategic planning of alternative destinations and travel itineraries, visitors benefit from a more varied travel offering, with the added value of better information and interpretation as well as any financial advantages of not driving (for example: not having to pay parking charges or hire cars currently used by most overseas visitors to England (English Tourist Board and Tourism Management Institute, 2003)). This helps the many visitors who prefer not to drive (VisitEngland, 2008) (for example: $45 \%$ of visitors to the Lake District want to reduce their car use while in the National Park (Lake District National Park Authority \& Cumbria County Council, 2011)).

The greatest benefit to visitors is derived in car-free destinations such as Gemeinschaft autofreier Schweizer Tourismusorte (GaST), a community of car-free tourist resorts and the Alpine Pearls, a collection of 28 destinations in six European countries, offering holidays away from 'traffic noise and exhaust fumes' (Alpine Pearls Association, 2011) with alternatives to car use and good public transport connections with originating areas. The travel offering varies between villages, but includes electric vehicles, shuttle buses, horse-drawn carriages and ski lifts and many of the resorts provide an inclusive "guest card" for free transport and discounts in the area (Alpine Pearls Association, (2011) and Simpson et al., 2008, p. 94).

Guests profit from the high quality of the air and the privilege and freedom of being able to move around the village safely' (Gemeinshaft autofrei Schweitzen Tourismusorte, 2013).

Several islands around the world have also made a virtue of their lack of transport to offer car-free experiences (such as Sark and Herm in the Channel Islands: (Romeril, 1985), Gili Trawangan in Indonesia (Dodds, Graci, \& Holmes, 2010) and the Turkish Prince Islands (Edgü and Cimşit, 2011)). In most areas, however, the benefits of going car-free for the individual are mitigated by still experiencing the traffic generated by other visitors and residents.

Integrated ticketing (e.g. London Visitor Oyster Card (Transport for London, 2013) and the Swiss Travel Pass (MySwitzerland, 2012)) form one aspect of visitor travel planning. Travel cards may also grant free public transport use (e.g. Konus card in the Black Forest (Ruoff, 2012) and GUTi card in Bavaria (Wibmer, 2012) (funded by a small bed-night tax (Hilland, 2010))) or free (e.g. ZürichCard (Zürich, 2013), Oslo Pass (VisitOlso, 2013)) or discounted entrance (see Hong Kong's MTR Tourist Day 
Pass (Hong Kong Tourist Board, 2013), Melbourne's myki Visitor pack (Public Transport Victoria, 2013) to local attractions.

Better visitor-oriented information and information about alternative modes (for example about cycling, see Arcotel Hotels, 2011) again improve the visitor offering. Itineraries (see German National Tourist Board, 2013), timetables, location of toilets, gradients for cyclists, degrees of difficulty for walkers (see Ohakune Old Coach Road, Department of Conservation, New Zealand, 2013) estimates of journey times (Norfolk Green, 2013) and walker/cyclist friendly accommodation and hostelries all help promote more sustainable travel, while the use of different media such as apps (Cade, 2013) can provide real-time information and customised interpretation.

Increasing the intrinsic value of the travel experience can encourage the use of non-car modes. Provision of novel ways of travelling such as by boat (e.g. gondolas in Venice), vintage bus (Glacier National Park (Daigle, 2008, p. 59) Trossachs Trundler, (Scotland), open top bus (City Sightseeing Worldwide), electric car (New Forest, Brand New Forest, 2013) and Brecon Beacons twizies (Chester, 2013) or electric bike (Lake District National Park Authority, 2013a and Lake District National Park Authority, 2013b) enhances fun and excitement. While themed itineraries and interpretation add coherence to routes (for example the Coast and Castles cycle route between Newcastle and Edinburgh, Cook's Lookout Trail in Newfoundland (National Geographic, 2012)), better signage, livery, branded publicity and staff training (Lumsdon \& Caffyn, 2012) all help to improve the visitor experience.

Visitor travel planning has the potential to open up the area to new markets, such as people from households without cars (25\% of UK households in 2011 had no car (Department of Transport, 2012) many of them relatively wealthy, urban households (Wood, 2009), overseas visitors (70\% of whom arrive without a car (English Tourist Board and Tourism Management Institute, 2003)) and those who prefer not to drive. If they perceive the area is not suitable for holidays without a car, these visitors will go elsewhere or stay at home (South Downs National Park Authority and New Forest National Park Authority, 2012). Where road and parking constraints limit capacity, diverting potential visitors to alternative modes can increase the number of visitors without extending parking areas or widening roads.

A benefit of slowing visitors down is that they are more likely to spend money in the locality (Halden, 2013). Long distance cycle routes (Downward et al., 2009 and Lumsdon et al., 2004) and walking trails have been found to generate extra spending in the areas they pass through and there is evidence that walkers and cyclists spend more than car-borne visitors in local shops, cafes, pubs and restaurants (Wood, 2009) which keeps money in the local economy. This delivers greater benefits (White, 2010) through the local multiplier effect than money spent in nationally/internationallyowned chain outlets or on petrol.

Residents benefit from reductions in local traffic especially if this reduces congestion or parking problems. They are often able to avail themselves of improved travel provision whether that is better public transport or infrastructure for cycling and walking. The environment globally is improved by reductions in greenhouse emissions, and locally with less pollution, noise, danger, etc.

However, while it appears that visitor travel planning offers benefits to most parties involved in tourism within a tourist destination area, organising its delivery is problematic. Many of the measures require considerable investment and planning, for example it takes 3-4 years for a leisure bus service to achieve full patronage (Gronau and Kagermeier, 2007 and Speakman and Transport for Leisure Ltd, (2008a)). As with most aspects of destination planning, visitor travel planning 
involves co-ordination, strategic thinking and action by groups of stakeholders, as discussed in the following sections.

\subsection{Destination stakeholders and partnerships}

This section reviews the literature about the formation and functioning of destination partnerships and some of the challenges they currently face.

Partnerships and collaborations have long been a feature of destination management, partly because of the significant number of small enterprises involved in tourism (Bramwell \& Lane, 2000, p. 1). More recently, there has been a global push towards greater involvement of the private sector in activities which were previously undertaken or funded by public sector organisations (Hall, 1999 and Selin and Chavez, 1995, pp. 844-845; Stanford, Carter, \& George, in press). They have also been viewed as a way of reaching sustainable tourism goals (Laing, Lee, Moore, Wegner, \& Weiler, 2009: 208) and of introducing the public interest in decision-making (Mccool, 2009, p. 133).

Partnerships and collaborations involve independent stakeholders pooling some of their resources: investment, knowledge, skills and time for common benefit (Lasker, Weiss \& Miller, 2001).

Stakeholders are defined as 'any group or individual who can affect or is affected by the achievement of the organisation's objectives' (Freeman, 1984, p. 5). This differentiates between active "can affect" and passive "is affected by" types of stakeholder. Climpson (2008) applies this distinction to destination management. He groups stakeholders into those 'who must lead and set an example by taking co-ordinated action and facilitating the participation of the remaining stakeholders' such as the public sector, industry and landowners and those who cannot 'be expected to initiate action of their own, but whose engagement and participation is essential for the success and sustainability of any plan' such as residents, tourists and environmental interest groups. He and the New Forest District Council developed the (Clegg \& Gutic, 2013) (Visitors, Industry, Community and Environment) VICE model to describe the stakeholders in a destination's management, which evolved into the Visitors, Environment, Residents and Businesses (VERB) model (Fig. 1) used in tourism management theory aimed at the public sector (Climpson, 2008).

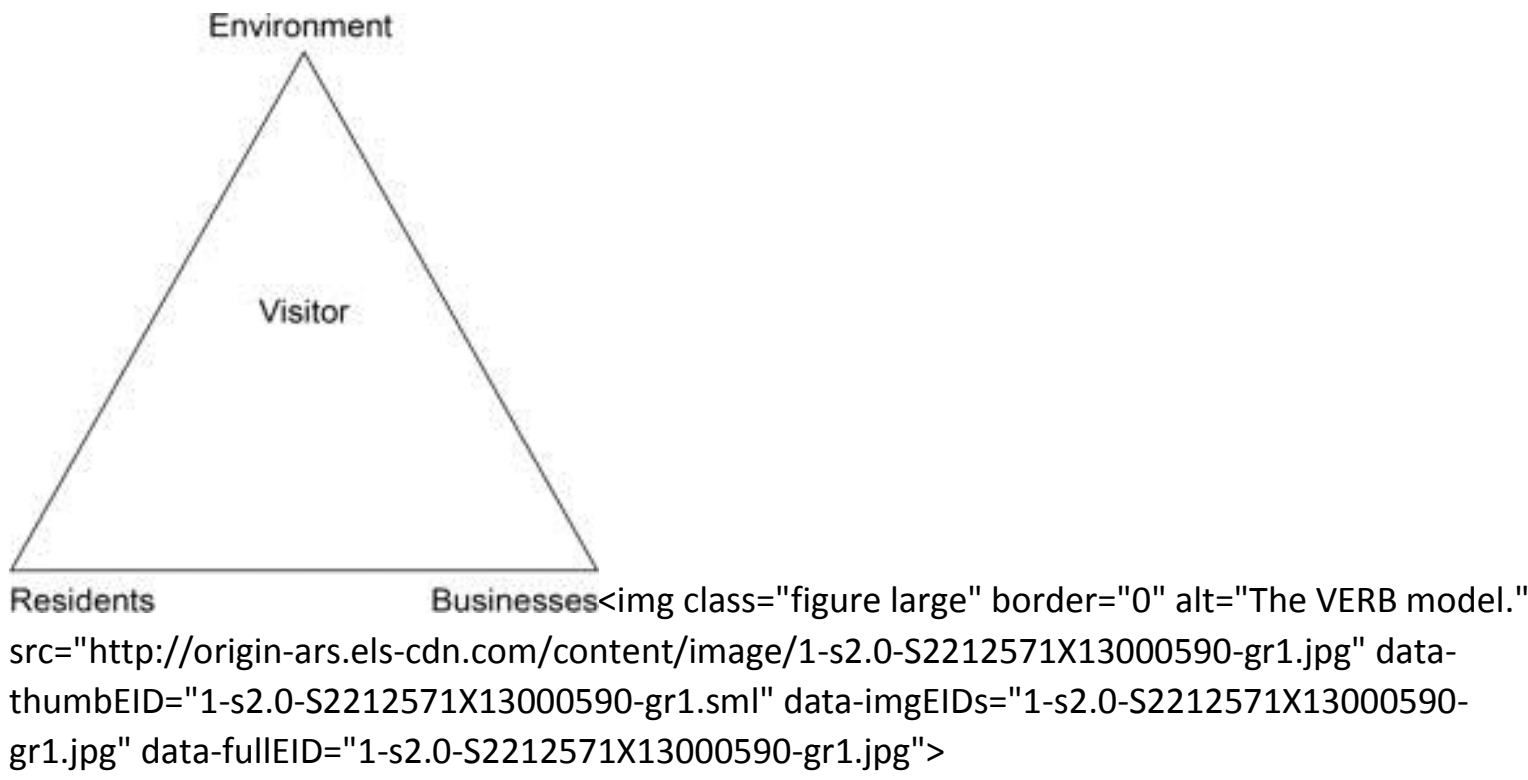

Fig. 1.

The VERB model. 
Figure options

Download full-size image

Download as PowerPoint slide

However, these represent idealised versions of who should be included in any partnership managing a tourist destination area. They contrast with the "messy" reality (Dredge, 2006, Hall, 1999 and McCool, 2009) of collaborations between stakeholders with varying degrees of power, influence and resources and different goals, aspirations and potential to benefit from collaboration (Brinkerhoff, 2002).

Partnerships to help guide local tourism policy and direction may bring increased democracy, equity, operational advantage and a better tourism product (Bramwell \& Lane, 2000, p. 2; Brinkerhoff, 2002). However, Jamal and Getz (1995, p. 200) warn that 'perceived interdependence and key stakeholder involvement are not adequate for achieving success'. A number of problems have been identified with the effectiveness and functioning of tourism partnerships leading Fyall $(2011$, p. 343) to doubt whether destinations' direction and quality can be influenced or controlled "unless all elements are owned by the same body". Lack of funding and political will has reduced many destination "management" organisations to destination "marketing" organisations (Pike, 2013) with organisations whose remit has not traditionally been destination management stepping in to fill this void (Stanford et al., in press). Partnerships may include, or indeed exclude, parties with very different access to resources and power (Hall, 2000, p. 149), for example visitors' views are often not solicited (Stanford, 2008).

Potential partners may not engage, particularly if they suspect some parties are "free-loading", for fear of losing control, resorting to more familiar strategies, even if previous outcomes had been suboptimal (Jamal \& Getz, 1995, p. 201). Dredge (2006) describes a series of 'cycles of participation, competition and disaffection' with different networks attempting to promote tourism around Lake Macquarie in Australia between 1997 and 2000, which aptly applies to many other areas' endeavours to establish effective partnerships to promote their tourism offer.

Even where partnerships are formed, they can create a forum for a clash of cultures, particularly between public authorities, favouring 'top-down' implementation, and communities and businesses more familiar with 'bottom up' development (Wray, 2011). Public administrations also have nested links with other tiers of government making them less reactive to local circumstances (Eagles, 2009, Hall, 2000 and McLennan et al., 2012) and slow to respond (UNWTO, 2007). This makes achieving horizontal and vertical links to ensure tourism policy co-ordination the greatest challenge for effective tourism governance (OECD, 2012).

Tourist destination areas, where their borders can be defined, often do not conform to local administrative areas, let alone those of local transport providers. Thus partnerships may find themselves representing portions of different levels of administration. Lake Constance epitomises the problem of geographical and structural misalignment, being a cross border destination area, within three countries: Germany, Switzerland and Austria and very close to Lichtenstein, all with different administrative hierarchies. Despite having an umbrella destination area organisation, its management is characterised by the diverging interests of stakeholders (Reghage, 2010).

Opportunities to introduce more sustainable travel within the area are pursued by stakeholders who favour 'isolated stand-alone solutions. Actions are not coordinated on the destination level, they stay fragmented' (Thimm, 2012). 
As well as spatial misalignments, temporal boundaries may differ, such as the duration of a season, budgeting time units and the speed to react to or implement changes (Dredge, 2006, p. 271). Partnership formation also requires time commitment from its members. Caffyn (2000) reports how some private sector members of a northern English partnership lost a day from their "fragile" businesses to travel to and attend meetings.

The formation and maintenance of a partnership has its own dynamic, including stages of establishing of communication, trust and commitment (Wang \& Xiang, 2007, p. 79). Caffyn (2000), in her investigation of the rise, demise and eventual disbanding of a tourism partnership in Northern England, suggests such collaborations may have a life cycle. The vitality of partnerships can reflect the flow of funding streams (Caffyn, 2000 and Laing et al., 2009) or progress, but the motivations and functions of the partnership may change as it develops 'more as a result of what is happening rather than from the businesses initial ambitions and strategic goals' (Wang \& Xiang, 2007, p. 78). Processes also create their own 'path-dependency', so that the organisation, system of governance, strategies and ethos become shaped by sets of circumstances, which then change faster than the institution. Gill and Williams (2011) describe how a pro-growth approach had been "locked-into" by the management of Whistler in Canada and how this was not appropriate to the challenge of becoming more sustainable, needing a more corporatist model of governance.

As well as being dynamic associations, tourism partnerships exist within volatile environments (Jamal and Stronza, 2009 and World Economic Forum, (2009)), being subject to a number of changes over which they have no control. This has led some authors (Beritelli et al., 2013, Hall, 2004 and McLennan et al., 2012) to question whether destination management organisations have the agency to influence how destinations develop or whether more powerful social trends will override any local action. Beritelli et al. (2013) see tourist destinations as subject to a number of factors beyond their control such as the development of alternative destinations and changing consumer preferences. They and Dredge (2013) stress that destinations are not static entities, with different constructions by different actors, existing in a fluid environment with a range of agencies, and policy cycles with different time lags (Mclennan et al., 2012). Hall (2011) also links the lack of progress in sustainable tourism to an ideology fostering growth and competition.

While not denying the influence of external factors, Beritelli et al. (2013), Mclennan et al. (2012) and Wang and Xiang (2007) imply that 'change can be influenced by collective human action' (Mclennan et al., 2012, p. 169). Wang and Xiang (2007) identify external stimuli, such as crises, economic and technological change, as common pre-conditions leading to partnership formation, others being: existing networks, a third party convener and visionary leadership. Speakman and Transport for Leisure Ltd (2008a) also stress the importance of a 'champion' within the partnership with the necessary 'drive, energy and enthusiasm' to ensure the partnership's success.

\section{Context of paper}

This paper results from discussion and thought about why what seems a simple way of reducing the environmental impact of visitor travel is rarely implemented. It reflects on our combined experience of researching, investigating and observing tourist travel in rural UK destinations in the last decade through consultancy projects, attending meetings of local destination stakeholders and talking to destination managers, transport providers and other stakeholders.

The evidence includes reports of projects, newspaper accounts, our own research and interviews conducted both specifically for this paper and in the course of previous projects. Three projects in particular have contributed to the paper: 
What makes you Move (see Stanford, 2013), a project commissioned by Cumbria Tourism, Natural England and Friends of the Lake District, examining the visitor segments most likely to contribute to local spending without large carbon footprints and to identify the messages which might influence their travel behaviour,

Seasonal Buses (see Guiver \& Davies, 2013), an ESRC funded project, surveying bus passengers in nine rural areas,

Tourism on Board, its predecessor (see Guiver and Lumsdon, (2006) and Institute of Transport and Tourism, (2007)), involving bus travel in 18 rural areas.

This paper now considers how visitor travel planning might be achieved and funded and the relevance of theories about partnerships in helping to explain the current failure to develop plans to improve the tourist offer while reducing the environmental impact of tourist travel with destinations.

\section{Instruments of visitor travel planning}

Visitor travel planning endeavours to promote and provide alternative modes, attractions and activities to help reduce visitor car use and its associated environmental impacts. The main instruments of visitor travel planning are provision and promotion. The destination manager's "journey" tends to be the reverse of the customer journey or sequence as outlined by UNWTO (2007) (dreaming, planning, booking, experiencing, remembering) with provision preceding promotion.

\subsection{Provision}

Travel involves nodes, where travel begins/ends or where routes and/or modes intercept each other forming networks. Provision includes enhancing aspects of nodes, routes, networks and vehicles. Tourism suppliers such as accommodation and other hospitality providers, attractions and communities may individually or collectively be able to improve nodes as these are site-based. Improvements can include installing lockers for bikes or luggage, benches and shelters, toilets, refreshments (see Lumsdon \& Caffyn, 2012), offering information and interpretation and making sure staff interacting with visitors are knowledgeable about the range of travel options available.

Routes and networks, and in the case of public transport, services, require a more area-wide responsibility, such a National Park, local highways authority, bus or train provider. The size and density of the network depends on the number of routes and their connectivity. Often adding relatively small links can greatly increase the connectivity of a network (Sustran's Connect2 project focusses on short links such as bridges and road crossings to extend foot and cycle networks (Flitcroft, 2007; Sustrans, 2013). Providing, improving or just signing short footpaths can facilitate links between bus stops and attractions, while minor detours of bus services may include new attractions into the network (Speakman and Transport for Leisure Ltd, 2008a). Facilitating the transfer from one mode to another increases potential personal networks, so a wider range of destinations can be reached on foot (for example linear walks along Pembrokeshire and North Norfolk Coastal Paths, Hadrian's Wall (Coulson, 2011; Hadrian's Wall Country, 2013; Roberts \& Rees, 2012)), or by bike if there are public transport connections and bikes are allowed on buses (Lake 
District). Back-up provision (e.g. advertised taxis - the MoorsBus will pay for taxis if the bus is delayed, but also available to passengers if they miss the bus (Lumsdon \& Caffyn, 2013, p. 69), mobile bike repair services (such as provided by Cycle and Walk Holidays) and short cut paths back to settlements) helps develop confidence in using the network.

Public transport networks offer more potential destinations when there are close (in time and space) scheduled connections allowing people to transfer from one mode or route to another (The Moorsbus's co-ordinators provided at their hubs helped and reassured passengers changing from one service to another (Speakman and Transport for Leisure Ltd, 2008b)). Perceived networks can be extended through integrated ticketing, allowing travel on different companies' services (for example the FalMussel card (Cornwall FalRiver, 2013) allows travel on local boats, buses and trains). This not only removes the marginal cost, but also the "hassle factor" of buying a ticket at every interchange.

Frequently the spatial and temporal network of public transport reflects residents' rather than visitors' travel patterns, for example with fewer or no opportunities to travel on Sundays (Speakman and Transport for Leisure Ltd, 2008a). A study of tourism flows in the Lake District, found that many of the destinations and routes frequented by car users were unavailable by public transport (Kirkbride, 2013). The temporal extent of a public transport network can be increased by extending the operational season and day, although limited funding can force providers to decide between a longer season or higher frequency of service (Speakman and Transport for Leisure Ltd, 2008b, p. 14).

The quality of routes can be improved through en-route information for reassurance (signage on walking and cycle routes (see Visit Sefton and West Lancashire, 2013), branded liveries on buses (Hill, 2013) (the New Forest even brand each route with a different colored bus (Donovan, 2013), timetables different coloured bus (Donovan, 2013), timetables on vehicles (Speakman and Transport for Leisure Ltd, 2008b) and real-time information at stops (Lancashire County Council, 2013) for public transport services). Interpretation, from guides, brochures (see First Group, 2013), audio commentaries (Donovan, 2013), phone apps, signage of what can be seen or heard from the route/vehicle help the visitor engage with the area. This is particularly relevant for themed routes (see Hadrian's Wall Country, 2013) when the interpretation can explain the connections and help deliver a coherent narrative. The quality of the service will also be judged by its vehicles and equipment, whether they are clean and well-maintained, and the helpfulness and knowledge of the people delivering the service.

\subsection{Promotion}

The customer's starting point to using sustainable travel within a destination area may be "inspiring" promotions (UNWTO, 2007) leading to searching more practical information of how to access the inspiration. The destination manager, however, has to first ensure that the customer can obtain the necessary information in a user-friendly form before launching the inspirational material. To be successful the same information needs to be delivered consistently through a variety of media and channels. For example, the same routes may feature in publicity about "how to get here" issued by attractions (destination orientated), "days out" issued by accommodation providers (originorientated) and "getting around the area" (area-orientated) issued by tourist information outlets.

Confidence in the network starts with confidence in the information, so lack of consistency can undermine trust (see New Forest National Park, 2013), leading to tourists resorting to car use as well as leaving a bad impression of the area. Accommodation providers and others in a position to advise tourists must have confidence in the service themselves to instill it in others. Special or guided trips 
or free tickets for these "intermediaries" have proved valuable means of "spreading the word" (Moody, 2004).

The need to give temporal information about public transport makes it particularly difficult for giving simple, easy to follow, yet comprehensive information. Where there is some control over the services, it may be best to adapt them to easy explanation, for example having an "clockface" hourly or more frequent regular service, so the information can state "buses/trains leave here at ten past the hour" or "every 15 minutes".

This also makes public transport information prone to becoming out-of-date. Again, where there is control or agreement, the dates of changes in service can be agreed with the operators, preferably to coincide with seasonal boundaries and the publicity print-runs (The Explore the Cotswolds by Public Transport project accommodated changing timetables by supplying monochrome, easy-toprint, timetables within their promotional booklets (Speakman and Transport for Leisure Ltd, 2008b)). Train operators, often with pivotal services to and from the destination, are probably least likely to be able to accommodate the destination's requirements because of agreed running slots on lines and connections outside the area. Changes to their services can invalidate tourist timetables prepared over a long time and with large print runs (Dinmore, 2010). Increasingly there are more flexible media which visitors can check closer to their arrival date.

As potential visitors progress from inspiration to planning and confirming, they will require finer details of information. Interviews with visitors to the Lake District (Guiver, 2006) revealed the importance of perceptions and the need for different kinds of information. A few had chosen the area, as they had the impression it was well provided with public transport (one contrasted it to Scotland, an alternative destination). Another spoke of wanting help in choosing accommodation with good public transport links. This need that was not fulfilled by conventional journey planners, which start with the question 'where do you want to go?' answering with information about how to get there, whereas he wanted to stipulate the mode and ask where to go.

Inspiring people to visit an area often relies on imagery and emotions. Encouraging them to use active modes and public transport needs careful thought about how to present images of the kind of people they identify with or aspire to be. Derogatory, connotations, particularly of public transport users, need to be avoided or contradicted. Depicting the special qualities of the area and how they relate to travel options requires skill and subtleness. Intermediaries with direct experience of travelling within the area, such as journalists and travel writers (for example Iseard, 2009), can help portray the attraction of such holidays.

However, to avoid disappointment and so the failure to return, the product must match the promotion and information. A carless family will not be enamoured with an area promising a freedom ticket to travel, if they find there is only one bus a week.

\section{Funding and organisation}

This section examines the possible sources of funding for aspects of visitor travel planning before describing some of the problems encountered implementing travel facilities for visitors.

\subsection{Visitors pay}

Relatively small transfers of passengers from car to public transport represent large increases in patronage. If these extra passengers are accommodated on existing services, particularly at off-peak times, they can help lift them to commercial operation (Speakman and Transport for Leisure Ltd, 2008a). However, commercial transport providers often need evidence that new offers will increase 
patronage not abstract it from existing trade. A few operators have realised the potential, often with the help of local authorities, National Parks or other public authorities. Norfolk Green set up the Norfolk CoastHopper with help from the North Norfolk Coast Partnership but has managed to improve the offer to visitors with more frequent and better quality buses on a nearly commercial basis. Repeat visitors graduate from seeing the bus, to using it for day trips and then realising they can reach their accommodation by train and bus directly and arriving without their car.

Promotion and provision of facilities such as footpaths, signage and bus stops are rarely paid for directly by users and it is difficult to provide the mechanisms to enable this. Voluntary payments may be solicited through visitor payback schemes such as "Fix-the-fells" whereby visitors are asked to contribute to the cost of repairing and maintaining footpaths in the Lake District. Set up costs are high, requiring channels for collection such as 'collection boxes, collection envelopes or donation leaflets in hotels, B\&Bs, car parks, attractions, shops, buses or ferries' (Chapman, 2008). Increasing visitors' engagement by identifying the locations/repairs bought with each donation can raise more funds. For example, a Langdale Company sold "metres" of footpath repairs with a certificate and map reference (Royce, 2002) prompting donors to visit their stretch, often paying for another metre.

With voluntary opt-out schemes, businesses add a small percentage to bills, which the customer can opt not to pay. Accreditation for participating businesses (Collier, 2002) and showing "the green ticket" (Scott, Christie, \& Tench, 2003) enhance uptake. However, there seems no appetite for local bed-night taxes as exercised in parts of Germany (Hilland, 2011) and Italy (see City of Venice, 2011).

\subsection{Businesses pay}

Another way to finance visitor travel planning is through the businesses that benefit from the improved visitor offering. The New Forest has successfully started two new New Forest tours underwritten by attractions along its route.

The evidence from the visitor figures and surveys of the first New Forest tour convinced the target attractions of the benefits to them (Gregory, 2011). Breadalbane (Central Scotland) tourism businesses clubbed together to organise a similar tour (Scottish Enterprise, 2012) which is partly funded by local authorities and concessionary travel re-imbursements.

Guiver, Lumsdon, and Weston (2006) found that visitor travel was not a priority for tourist attractions along Hadrian's Wall, with the managers more concerned about preserving the archaeology, enthusing visitors and maintaining or increasing footfall and incomes. Although keen to encourage arrivals by visitors not travelling by car, they perceived them as completely separate markets to the car-borne visitors, whom they felt were more willing to change destination than mode. Another barrier to participating in co-ordinated visitor planning was the rate of institutional change (for example proposed changes of ownership), which created a form of paralysis, whereby staff could only focus on their key functions and were unable to contemplate improvements to more 'peripheral' activities (Guiver et al., 2006).

\subsection{Public authorities pay}

Tourism, with its fragmentation and the large number of micro-medium sized suppliers which 'both compete and co-operate with one another' mean 'it requires coordination of government, at the national and sub-national level' (OECD, 2012). These include authorities such as national and regional governments, Unitary, District County and Regional Councils and National Parks who pay in their roles as the transport providers (for footpaths, cycleways, roads and certain kinds of infrastructure), enablers and planners of public transport and supporters of local tourism. 
Each level in the hierarchy of civic administration has different responsibilities and income streams. For example in the UK, District Councils, which are concerned with local planning and receive incomes from businesses as well as car parking revenues, are often responsive to the needs of tourism businesses in their area, especially where they are a substantial proportion of the total number of businesses (Moody, 2013). County Councils deal with much larger areas and strategic planning, their budgets fund education, social services and they have recently taken responsibility for some public health matters. They also deal with transport planning and have to balance the needs of several districts with different mixes of employment and deprivation. Local Parish Councils vary considerably in their effectiveness, but those of larger towns and villages can exert considerable influence (Moody, 2013).

Public transport routes tend to cross administrative borders, which may inhibit attempts to run services between urban and rural areas (Speakman and Transport for Leisure Ltd, 2008b, p. 41). This can also lead to conflicting interests and disputes about the distribution of subsidies and revenues especially when priorities or administrations are changing. The joint funding of Hadrian's Wall bus by Cumbria County, Northumberland Councils and other partners was threatened by Cumbria County Council's decision to cut the budget for bus subsidies (Proctor, 2011). Local protests about utility bus cuts made it difficult to justify funding a bus, which largely takes visitors out of Cumbria. However, withdrawal of a major partner also threatened the total visitor offer provided by the bus which carries over 36,000 passengers a year (Northumberland Tourist Information and Northumberland Accommodation, 2013).

Reductions in local government spending can directly impact on services. (For example cuts in spending on Welsh buses have reduced services and seasons in Pembrokeshire and the Brecon Beacons and threaten those on the Gower Peninsular (Clark, 2013)). The Clwydian Ranger network was stopped in 2012 (Clark, 2013), likewise the long-running Moorsbus seasonal service on the North York Moors ends this year (BBC York and North Yorkshire, 2011). The uncertainty about public authority spending also makes planning difficult even with guarantees of a service in the next season. For the Hadrian's Wall bus, this delays issuing timetables and prevents other outlets advertising the service which affects the travel plans of incoming tourists, especially from overseas (Moody, 2004). Yet it has run for over 30 years, previously received funds from a number of public authorities (Richardson \& Nichols, 2004) and has often been heralded as model service (see Reeves, 2006).

One area which appears to have united interests is Greenways in Pembrokeshire, notwithstanding the reductions in service referred to above. It provides seasonal bus services for walkers, opening and promoting walking and cycling routes and upgrading facilities and connections with inbound and outbound train and coach services (Roberts \& Rees, 2012). Its success is possibly due to the establishment of a separate administration, with early funding from a European project, which brought together a number of organisations with different aims (such as promoting tourism, conserving and educating about the countryside, accessibility for disabled visitors and residents) which were served by the provision of better transport, information and coordination. However, its Havenlink boat service supported by Milford Haven Port Authority and South West Wales Tourism Partnership was stopped after three years because of lack of funding (Pembrokeshire Greenways, 2012). Roberts (2013) reports that reduced financial contributions from several partners makes it difficult to ensure their engagement in decision-making. There is also less enthusiasm to help maintain schemes once they are up and running, than when they are being started (Roberts, 2013).

National Parks and conservation areas are more likely to have boundaries corresponding to those of the destination area. National Parks' remit (in the UK) is to conserve their natural beauty, wildlife 
and cultural heritage and promote the understanding and enjoyment of their qualities to the public, while fostering the economic and social well being of local communities (Reeves, 2006), all of which supports visitor travel planning. However, transport was found to be an early victim of reduced budgets (Reeves, 2006). Increasingly National Parks are becoming more directed towards their commercial revenues as public funding reduces (Kirkbride, 2013).

\subsection{NGOs}

In a few cases, NGOs fund the provision of some local tourist travel. Friends of the Lake District helped finance and promote routes in the Lake District, until research showed the routes were not viable (Kirkbride \& Moore, 2009).

However, there are examples of voluntary organisations organising local tourist travel facilities. Possibly the most successful in the UK is the Dales and Bowland Community Interest Company, run by volunteers who work with local bus companies to design the routes and seek out funding to support seasonal and year-long bus services for visitors to the Yorkshire Dales and Forest of Bowland Areas. They tap into a variety of funding resources, such as the National Lottery Fund, the European Union, local County and District Councils, charities and concessionary travel re-imbursements (Speakman, 2011).

Sustrans, a national NGO devoted to cycling and walking, organises the provision and promotion of long distance trails and routes such as the C2C (C2C Guide, 2013), Coast to Coast between the coasts of Cumbria and Northumberland (Northumberland National Park, 2012) (built with funding from the Lake District National Park Authority, 2013a and Lake District National Park Authority, 2013b, several local authorities, a tourism partnership and other NGOs (Cycle \& Walk Holidays, 2013)). Nurture Lakeland (2010), another NGO which mobilises funding from its members and a variety of grants, has trialled the provision of information about local attractions and access by foot, cycle and bus to accommodation user through brochures and phone apps in its 'Fresh air is Free' project (Cade, 2013).

\subsection{Mixed funding}

From these descriptions, it is obvious that most schemes need funding from a variety of sources and partnership leaders often spend a lot of effort and time identifying and bidding for possible funds. They also need to align the proposed project to the goals of partnership members, which may not be well articulated. An activity at a seminar for professionals involved in transport provision for tourists in rural areas revealed surprising differences in priorities. Bus operators and National Park employees put a high priority on reducing car use, with NGOs and academics prioritising social inclusion. Public servants appeared to want to meet all the aims (health, local spending, social inclusion, reduction of car use) with the result that their resources were spread very thinly (Guiver, 2011b).

The sheer number of organisations involved in each of these projects demonstrates the coordination and collaboration necessary to deliver some aspects visitor travel planning. (For example the Brecon Beacons National Park Authority (2007) lists 15 funders including the Brecon Beacons National Park Authority, four County Councils, six City or Borough Councils, a local tourism partnership, a passenger transport unit, the Forestry Commission Wales and the National Trust, an NGO. It is estimated that this service generated over $£ 220,000$ tourism spending in the area (Clark, 2013). Hadrian's Wall Partnership had 18 core funders (Morris, 2003). 
Snowdon's Green Key initiative uses revenues from local car parks to help fund a bus service for visitors. This has been prompted by severe problems of congestion on local roads and in neighbouring towns, which have been addressed by the bus service and parking restrictions (Jones, 2010).

What is also evident, revisiting the websites of projects is the number who have ceased or are planning significant reductions in services in the coming year (see Cotswolds Area of Outstanding Natural Beauty, Heather Hopper, Moorsbus, Shropshire Shuttles).

\section{Discussion}

This paper was inspired by our own curiosity about why visitor travel planning, with all its apparent benefits for visitors, residents, tourism businesses and the local and global environment is hardly practised in UK rural tourist destinations. Although we have described a number of initiatives, few aspire to be whole-destination-area visitor travel planning and most are mode-specific or local efforts to offer an alternative to car use and accommodate visitors without cars. The reasons for the lack of planning could include: not knowing about the benefits, not knowing how to help reduce car use, the volatile tourism environment, inability to assemble the partners needed to co-ordinate long-term strategic planning, lack of will, leadership, resources or authority.

Project promotions usually mention the benefits to the environment and visitors (e.g. Shropshire Hills Area of Outstanding Natural Beauty (2013)) 'Kind on your wallet and kind on the environment' ( North York Moors National Park Authority, 2013). In some areas an initial audit of the environmental impacts, or more specifically the carbon dioxide emission equivalents related to visitor travel, was undertaken (see Small World Consulting Ltd, (2010) and Small World Consulting Ltd, (2012)) and some projects have assessed the $\mathrm{CO} 2$ savings of their initiatives (see Lake District National Park Authority \& Cumbria County Council, (2011) and South Downs National Park Authority \& New Forest National Park Authority, (2012)). However, it is notoriously difficult to calculate such figures (Peeters \& Schouten, 2006). Benefits to businesses are considered in some bid documentation (see Lake District National Park Authority \& Cumbria County Council, (2011) and South Downs National Park Authority \& New Forest National Park Authority, (2012)), although the implications of the local multiplier are mainly restricted to generic literature (e.g. United Nations Environment Programme and World Tourism Organization, 2012; Wood, 2009). However, it is evident that some projects calculate the spending associated with their initiative (see Brecon Beacons National Park Authority, (2007), Donovan, (2013) and Reeves, (2006)). Bids and plans also often include the benefits to residents and local tourism businesses (e.g. see Lumsdon \& Caffyn, 2012). Thus, while some benefits may be understated, there appears to be a general recognition that promoting car-free travel for visitors can bring environmental and economic benefits.

Although it is evident that expertise in transport provision and promotion exists within tourism destination management organisations, some small teams struggle to accomplish all the tasks required. Reeves (2006) describes a range of staffing levels and suggests this reflects differing commitments to sustainable transport. The lack of monitoring also means it has often been difficult to persuade potential funders of the benefits of the provision. Data about spending and reductions in car-use have often been important for securing additional funding (Gregory, 2011 and Reeves, (2006)).

Contrary to the descriptions of volatility experienced by international destinations (Beritelli et al., 2013 and Jamal and Stronza, 2009), the demand for these UK rural destinations is relatively stable, with some fluctuations due to the weather, big events such as the Olympics and other factors. 
Because the proportion of car users is so high (Small World Consulting Ltd, (2010) and Small World Consulting Ltd, (2012)) the market for alternatives is relatively large and so less susceptible to large fluctuations in demand. Indeed many of the projects have witnessed continued growth through their existence (Colson, 2011 and Gregory, 2011). Much of the volatility appears to have arisen from the changing political landscape, rather than the market.

As the literature described, it is difficult to include all the relevant stakeholders in a partnership to advance the interests of a tourist destination area (Dredge, 2006), let alone co-ordinate their goals into long-term strategic policy and provision. Potential partners may not engage because they fear too much commitment of their time and efforts (see Caffyn, 2000 and Jamal and Getz, 1995). The exact area of interest may be difficult to define (see Reghage, (2010) and Thimm, (2012)), power may be unevenly distributed (Hall, 2000) and some stakeholders may not be included (Climpson, (2008) and Stanford, 2008). There may also be a clash of cultures, particularly between partners in the public and private sectors (Wray, 2011). The processes of coming together and gaining mutual trust take time (Wang \& Xiang, 2007, p. 79) and partnership formation often only happens when certain preconditions are met (Wang \& Xiang, 2007).

Many of the projects described above demonstrate aspects of these difficulties. To plan and provide visitor travel depends on the co-operation of a number of stakeholders: transport providers, local authorities (usually of several different levels and including officers and elected representatives), local businesses often through their associations such as Chambers of Commerce and Tourism and Hospitality Associations, NGOs (such as environmental, leisure or transport users organisations) and ideally representatives of visitors and residents.

Transport Providers, largely commercial organisations, in the UK have different administrative areas and priorities. Rural tourist areas usually lie on the periphery of a train company's area and priorities. Their attention focusses on the outward connections towards their heartlands, although community rail partnerships have been able to demonstrate the benefits of tourist trade, particularly to branch lines (Dallen, 2007 and Wood, (2009)). UK bus companies have traditionally been more concerned about competition from other bus companies than that from car travel, or the opportunities that presents. Because of route licensing rules, local authorities cannot support services which might compete with or abstract patronage from commercial services, which hampers many tourist service initiatives (Kirkbride, 2011).

Although none of the projects described has as complex boundary and administrative differences as Lake Constance (Reghage, (2010) and Thimm, (2012)), many of the schemes straddle administrative boundaries (e.g. Brecon Beacons, C2C route (C2C Route, 2013), Hadrian's Wall bus), almost inevitable with long routes. This makes them prone to renegotiation of terms when partners' conditions or policies change, as illustrated by the threatened reduction of Cumbria County Council's funding of the Hadrian's Wall bus. Even destinations within one district are likely to form a portion of a larger administrative area. Where their interests compete with those of other areas, tourism tends to be low on the list of priorities, vying with concerns such as education, policing and social services. Unless tourism is perceived as a significant income and employment generator, elected councillors rarely see visitor travel as a priority, preferring to support services for voters, rather than visitors.

Services that meet leisure and tourism demands have not been seen as a high priority in times of funding cuts (Lumsdon \& Caffyn, 2012).

Local associations of businesses, such as Chambers of Commerce, Tourism and Hospitality Associations exert different degrees of influence over local priorities (see Dredge, 1999). Most 
destination management organisations are now funded by businesses' subscriptions rather than regional or national public funding and their focus is increasingly on marketing and promotion (Pike, 2013) and issues of sustainability and planning are dropping off their agendas.

Transport is not top of tourism agendas - Tourism organisations and businesses are facing challenging times with reduction in public sector support and a rapidly changing market and marketing media. Encouraging more visitors to use alternatives to cars in a deeply rural area is seen as very challenging and is rarely given a high priority (Lumsdon \& Caffyn, 2012).

The development of a partnership also creates its own dynamic, illustrated by the success of Greenways in Pembrokeshire, where it is proving more difficult to engage non-funding partners, especially now that services are established (Roberts, 2013). Initiatives, like partnerships (Caffyn, 2000) appear to have an attention life cycle and probably need revitalizing once they become stable.

As well as the internal dynamic of a partnership, each participating organisation will be subject to their own dynamic. Currently many are facing severe cutbacks following the financial crisis. The reductions in public spending and loss of a significant number of employees, means that even when officials recognise the value of visitor travel planning, they are unlikely to have any time to devote to it. In such times strategic planning, design of appropriate provision and creative promotion necessary seldom come together with sufficient funding to demonstrate what could be achieved. In the wider context, the recent move of responsibility for local tourism from Regional Development Agencies to Local Enterprise Partnerships is likely to produce uncertainty, loss of expertise and working relationships for a temporary period (Coles, Dinan, \& Hutchison, 2012). Instability and uncertainty amongst stakeholders along with shrinking budgets also tend to retrench organisations' activities into their core functions (Guiver, et al., 2008). As Reeves (2006) observes 'sustainable recreational transport ... is well known for falling between the gaps in terms of policy, funding and delivery.'

There seem to be a number of contributing factors to the several successes reported in providing alternatives to car travel within a region. Bringing together the partners necessary to make visitor travel planning work requires energy and vision and the ability to "sell" the idea on a number of fronts. This requires strong leadership (perhaps the visionary leadership mentioned by Wang \& Xiang, 2007) and the ability to gain the trust of different types of organisation, which themselves need time to develop. Often, the success of schemes referenced is due to one person's persistence, vision, negotiating skills and sometimes willingness to take risks. We would suggest that this has been a major influence in the cases of the Brecon Beacons, Lake District, Moorsbus, New Forest and Yorkshire Dales. Existing networks (Wang \& Xiang, 2007) also seemed to have helped deliver ambitious plans in part of the Lake District where there were already active collaborations between the Lake District National Park Authority, Cumbria County Council, South Lakes District Council, Cumbria Tourism, Friends of the Lake District, Nurture Lakeland and other organisations.

Funding is invariably a major obstacle to visitor travel planning. The major schemes being enacted in the Lake District, New Forest and South Downs have been facilitated through grants from National Government departments. Grants (often obtained through numerous rounds of bidding) from the Countryside Commission, Rural Bus Challenge, Welsh Government Assembly, European Union, Big Lottery and other funders have "kickstarted" or maintained many of these projects. Yet it is difficult to have guaranteed funding for more than 4 or 5 years, scarcely allowing enough time for planning and patronage to build up (Gronau and Kagermeier, 2007 and Speakman and Transport for Leisure Ltd, (2008a): 10) before the end of the grant, although secured outside funding for a period encourages partners to come together, plan and co-ordinate action. 
With no obvious authority to implement sustainable transport for tourists, it is remarkable that so many projects have been implemented in different areas. However it requires effort, dedication and determination to co-ordinate so many agencies, each with differing goals, attract funding and navigate the continually changing organisational landscape. It is not surprising that many areas only manage a single project and few even attempt visitor travel planning.

\section{Conclusions}

The paper has presented the case for visitor travel planning to help reduce the environmental impact of visitor travel within a destination, influence modes of arrival, improve the local tourist offering and generate additional local spending. The literature review explored the environmental impacts of tourist travel, the use of travel planning for utility travel and how it differs from leisure travel. The section about stakeholders and partnerships underlined the "messiness" of local tourism alliances and their own changeability within an extremely volatile environment. It included some views that the development of any tourist destination is more likely to be influenced by external factors (markets, ideology etc.) than the efforts of a local tourism destination organisation.

The next sections set out the types of instruments used in visitor travel planning and our observations of their use in rural tourist destinations within the UK. The potential funding and organisational models were described in the next section along with how they have been put into practice. The discussion section describes some of the problems of implementing visitor travel planning and factors in the success of some of the projects observed.

The main barriers to visitor travel planning appear to be the absence or weakness of any agency which might implement it. The common factor for organisations involved in tourism destination management partnerships is that visitor travel planning is not their main objective. Yet, even if funding can be secured, the strategic thinking and planning needs to be co-ordinated in order to give visitors a comprehensive and coherent alternative to car use. Whether or not that is addressed through a formal partnership, it requires consultation and co-ordination with the organisations concerned with tourism and travel in the area: accommodation providers, attractions, retailers, transport providers, local authorities, local NGOs, etc. each with different degrees of cohesiveness and power to act in their members' interest. Although it may be instrumental in achieving their aims, which may diverge considerably, visitor travel planning will not be at the top of their agenda.

Reducing the carbon emissions from tourism and other human activities is of the upmost importance for the welfare of current and future populations and the planet. Within tourism, travel planning within the destination appears to provide a win-win-win situation, benefitting most stakeholders, including the local environment. Yet, the difficulties of organising, funding and coordinating appear to present barriers which can only be overcome when it comes to the top of the agenda of an organisation with the will and resources to implement it, helped by a determined individual who can push it forward.

\section{Acknowledgements}

The authors would like to thank the two reviewers for their helpful comments. Many thanks also to: Cumbria Tourism, Friends of the Lake District and Natural England who funded parts of the original research and to TEAM Tourism colleagues who collaborated on the What Makes You Move? consultancy report, ESRC for funding the Seasonal Buses project and the many destination and transport managers who have helped us in our research.

References 
Alpine Pearls Association, (2011)

Alpine Pearls Association (2011). Guarantee of quality by the Alpine Pearls: We promise you a perfect holiday [Online]. Available at: 〈http://www.alpine-pearls.com/en/soft-mobility/ourguarantee-of-quality.html〉; Accessed 06.06.13.

Ampt, (2003)

Ampt, E. (2003). Voluntary household travel behaviour change - Theory and practice. Moving through nets: The physical and social dimensions of travel 2003 Lucerne.

Arcotel hotels, (2011)

Arcotel hotels (2011). Hamburg: A cyclist's paradise [Online]. Available at: 〈http://arcotelhotelsen.blogspot.co.uk/2011/06/hamburg-cyclists-paradise.html〉; Accessed 23.09.13.

BBC York and North Yorkshire, (2011)

BBC York and North Yorkshire (2011). North York Moors national park to axe MoorsBus and jobs [Online]. Accessed 23.09.13.

Beritelli et al., 2013

P. Beritelli, T. Bieger, C. Laesser

The new frontiers of destination management: Applying variable geometry as a function-based approach

Journal of Travel Research (2013)

Beunen et al., 2008

R. Beunen, H.D. Regnerus, C.F. Jaarsma

Gateways as a means of visitor management in national parks and protected areas

Tourism Management, 29 (2008), pp. 138-145 
Article

।

PDF (312 K)

|

View Record in Scopus

।

Citing articles (8)

Bramwell and Lane, 2000

B. Bramwell, B. Lane

Introduction

B. Bramwell, B. Lane (Eds.), Tourism collaboration and partnership, Channel View Publications, Clevedon (2000)

Brand New Forest, (2013)

Brand New Forest (2013). Hire a Twizy and Tour the New Forest! [Online]. Available at: 〈 http://www.brandnewforest.com/twizy/〉; Accessed 25.06.13.

Brecon Beacons National Park Authority, (2007)

Brecon Beacons National Park Authority (2007). Beacons Bus: Activity report.

Brinkerhoff, 2002

J.M. Brinkerhoff

Government-nonprofit partnership: A defining framework

Public Admiinstration and Development, 22 (2002), pp. 19-30

View Record in Scopus

।

Full Text via CrossRef

I 
Citing articles (117)

C2C Guide, (2013)

C2C Guide (2013). C2C route: About the C2C [Online]. Available: 〈http://www.c2cguide.co.uk/about-the-c2c/〉; Accessed August 2013.

Cade, 2013

S. Cade

Use of apps

In Lakeland Sustainable Tourism Forum, Nurutrelakeland, Staveley, Cumbria (2013)

Caffyn, 2000

A. Caffyn

Is there a tourism partnership life cycle?

B. Bramwell, B. Lane (Eds.), Tourism collaboration and partnerships, Chanel View Publications, Clevedon (2000)

Carrington, (2013)

Carrington, D. (2013). Global carbon dioxide in atmosphere passes miiestone level: Climate warming greenhouse gas reaches 400 ppm for the first time in human history. The Guardian, 10th May.

Chapman, (2008)

Chapman, C. (2008). Visitor payback - Developing and implementing effective schemes. Tourism Insights 〈Available at

http://www.insights.org.uk/articleitem.aspx?title=Visitor\%20Payback\%20\%E2\%80\%93\%20Developin g\%20and\%20Implementing\%20Effective\%20Schemes Accessed 05.08.2013〉. 
Chester, T. 2013. Exploring the Brecon Beacons in a Twizy: a foodie's tour Read more. http://www.roughguides.com/article/exploring-the-brecon-beacons-in-a-twizy-foodtour/\#ixzz2iqzZmKOe〉. Rough Guides, Accessed 29.05.13.

City of Venice, (2011)

City of Venice (2011). Tourism - The tourist tax in the territorry of the municipality of Venice [Online]. Available at: 〈

http://www.comune.venezia.it/flex/cm/pages/ServeBLOB.php/L/EN/IDPagina/48016〉; Accessed 23.09.13.

City Sightseeing Worldwide?,

City Sightseeing Worldwide? City sightseeing worldwide [Online]. Available at: 〈http://www.citysightseeing.com/〉; Accessed 09.09.13.

Clark, (2013)

Clark, R. (2013). Eighteen nationalities on a Gower bus highlight fears cuts could threaten Wales' tourist appeal. WalesOnline, 5th August.

Clegg and Guitic, (2013)

Clegg, A., \& Guitic, J. (2013). Integrating the 'VERB' model into an undergraduate tourism management degree programme. In R. Atfield, \& P. Kemp (Eds.), Enhancing education for sustainable development in business and management, hospitality, leisure, marketing, tourism.

Climpson, (2008)

Climpson, A. (2008). Sustainable destination management: the VICE model. Tourism Insights.

Coles et al., 2012

T. Coles, C. Dinan, F. Hutchison 
May we live in interesting times? Changing public sector support for tourism in Engand during the sovereign debt crisis

Journal of Destination Marketing and Management, 1 (2012), pp. 4-7

Article

।

PDF (447 K)

|

View Record in Scopus

।

Citing articles (9)

Collier, (2002)

Collier, B. (2002). Visitor payback-An effective fundraiser? In L. Davies (Ed.), Visitor payback schemes: Countryside Recreation Network.

Colson, 2011

B. Colson

Moving around the North Norfolk coast

Funding buses in tourist areas, University of Central Lancashire (2011)

Connell and Page, 2008

J. Connell, S.J. Page

Exploring the spatial patterns of car-based tourist travel in Loch Lomond and Trossachs National Park, Scotland

Tourism Management, 29 (2008), pp. 561-580

Article

|

PDF (2273 K)

।

View Record in Scopus 
Cornwall Falriver, (2013)

Cornwall Falriver (2013). Getting about [Online]. Available at: 〈http://www.falriver.co.uk/gettingabout/fal-mussel-card〉; Accessed 23.09.13.

Cumbria County Council, (2013)

Cumbria County Council (2013). 4/9/2013 - Hadrian`s Wall Bus stays on the road for extra month [Online]; Accessed 04.09.13.

Cycle \& Walk Holidays, (2013)

Cycle \& Walk Holidays (2013). Cycle rescue [Online]. Available: 〈

http://walkandcycleholidays.co.uk/bicyclehire.html〉; Accessed 23.09.13.

Daigle, 2008

J. Daigle

Transportation research needs in national parks: A summary and exploration of future trends

George Wright Forum (2008), pp. 57-64

View Record in Scopus

Dallen, 2007

J. Dallen

The challenges of diverse visitor perceptions: Rail policy and sustainable transport at the resort destination

Journal of Transport Geography, 15 (2007), pp. 104-115

Article

।

PDF (418 K)

।

View Record in Scopus 
Citing articles (14)

Department of Conservation, (2013)

Department of Conservation, G. O. N. Z. (2013). Tracks and Walks: Central North Island: Ohakune old coach road [Online]. Available at: 〈http://www.doc.govt.nz/parks-and-recreation/tracks-andwalks/central-north-island/ruapehu/ohakune-old-coach-road/〉; Accessed 23.09.13.

Department of Transport, (2012)

Department of Transport (2012). Transport Statistics Great Britain. Department for Transport.

Dick Sisman \& Associates, (2007)

Dick Sisman \& Associates (2007). Tourism Destinations Carbon Footprints. The Travel Foundation.

Dickinson and Dickinson, 2006

J.E. Dickinson, J.A. Dickinson

Local transport and social representations: Challenging the assumptions for sustainable tourism Journal of Sustainable Tourism, 14 (2006), pp. 192-208

View Record in Scopus

|

Full Text via CrossRef

।

Citing articles (56)

Dinmore, (2010)

Dinmore, I. (2010). RE: Interview for Seasonal Buses Project. Type to GUIVER, J.

Dodds et al., 2010 
R. Dodds, S.R. Graci, M. Holmes

Does the tourist care? A comparison of tourists in Koh Phi Phi, Thailand and Gili Trawangan, Indonesia

Journal of Sustainable Tourism, 18 (2010), pp. 207-222

View Record in Scopus

।

Full Text via CrossRef

।

Citing articles (30)

Donovan, (2013)

Donovan, S. (2013). New open-top route launched in the New Forest. New Forest National Park Authority: Latest news, 26th June.

Downward et al., 2009

P. Downward, L. Lumsdon, R. Weston

Visitor expenditure: The case of cycle recreation and tourism

Journal of Sport \& Tourism, 14 (2009), pp. 25-42

View Record in Scopus

|

Full Text via CrossRef

।

Citing articles (18)

Dredge, 1999

D. Dredge

Destination place planning and design

Annals of Tourism Research, 26 (1999), pp. 772-791

Article

।

PDF (185 K) 
View Record in Scopus

।

Citing articles (65)

Dredge, 2006

D. Dredge

Policy networks and the local organisation of tourism

Tourism Management, 27 (2006), pp. 269-280

Article

।

PDF (202 K)

|

View Record in Scopus

।

Citing articles (167)

Dredge, (2013)

Dredge, D. (2013). Destinations and destination management. TriNet.

Eagles, 2009

P.F.J. Eagles

Governance of recreation and tourism partnerships in parks and protected areas

Journal of Sustainable Tourism, 17 (2009), pp. 231-248

View Record in Scopus

।

Full Text via CrossRef

।

Citing articles (39) 
Edgü and Cimşit, 2011

E. Edgü, F. Cimşit

Island living as a gated community: Place attachment in an isolated environment

ITU Journal of Faculty of Architecture, 8 (2011), pp. 156-177

View Record in Scopus

English Tourist Board \& Tourism Management Institute, 2003

English Tourist Board \& Tourism Management Institute 2003. Destination management handbook: A sustainable approach.

Flitcroft, (2007)

Flitcroft, C. (2007). Congratulations to Sustrans Connect2 [Online]. BMC. Available at: 〈 https://www.thebmc.co.uk/congratulations-to-sustrans-connect2〉; Accessed 23.09.13.

Freeman, 1984

R.E. Freeman

Strategic management: A stakeholder approach

Cambridge University Press, Cambridge (1984)

Fyall, 2011

A. Fyall

Destination management: Challenges and opportunities

Y. Wang, A. Pizam (Eds.), Destination marketing and management - Theories and applications, $C A B I$, Wallingford (2011)

Gemeinshaft autofrei schweitzen tourismusorte, 2013

Gemeinshaft autofrei Schweitzen Tourismusorte 2013. Criteria for evaluation [Online]. Available at: 〈http://www.auto-frei.ch/index.php/en/criteria-for-evaluation〉; Accessed July 2013. 
German National Tourist Board, (2013)

German National Tourist Board (2013). Germany: The travel destination [Online]. Available at: 〈 http://www.germany.travel/en/leisure-and-recreation/cycling/ilmenau-cycle-route-lueneburgheath.html〉; Accessed 23.09.13.

Gill and Williams, 2011

A. Gill, P. Williams

Rethinking resort growth: understanding evolving governance strategies in Whistler, British Columbia

Journal of Sustainable Tourism, 19 (2011), p. 629

View Record in Scopus

|

Full Text via CrossRef

।

Citing articles (33)

Gregory, 2011

C. Gregory

The New Forest Tour: Funding models and lots more

In Funding for buses in tourist areas, University of Central Lancashire (2011)

Gronau and Kagermeier, 2007

W. Gronau, A. Kagermeier

Key factors for successful leisure and tourism public transport provision

Journal of Transport Geography, 15 (2007), pp. 127-135

Article

।

PDF (914 K) 
View Record in Scopus

।

Citing articles (32)

First Group, (2013)

First Group. (2013). Coastlinx 53 Jurassiccoast [Online]. Available at: 〈

http://www.firstgroup.com/ukbus/dorset/assets/pdfs/journey_planning/booklets/X53.pdf $\rangle$.

Guiver, (2006)

Guiver, J. (2006). Tourism on Board 2006.

Guiver, 2011a

J. Guiver

Buses in Tourist Areas: Toolkit and findings

In Funding buses in tourist areas, University of Central Lancashire (2011)

Guiver, (2011)b

Guiver, J. (2011b). Seasonal buses. In Proceedings of the Transport Practitioners' Conference.

Guiver et al., 2008

J. Guiver, L. Lumsdon, R. Weston

Traffic reduction at visitor attractions: the case of Hadrian's Wall

Journal of Transport Geography, 16 (2) (2008), pp. 142-150

Article

।

PDF (588 K) 
View Record in Scopus

।

Citing articles (12)

Guiver and Davies, (2013)

Guiver, J., \& Davies, N. (2013). Assessing the value of bus services for leisure. In Scottish Transport Applications and Research Conference.

Guiver and Lumsdon, (2006)

Guiver, J., \& Lumsdon, L. (2006). Tourism on board: Report of survey of Buses in Tourist Areas: August 2005.

Guiver et al., 2006

J. Guiver, L. Lumsdon, R. Weston

Visitor attractions, sustainable transport and travel plans - Hadrian's Wall: A case study

Managing Leisure, 11 (2006), pp. 217-230

View Record in Scopus

|

Full Text via CrossRef

Hadrian's Wall Country (2013)

Hadrian's Wall Country (2013) [OnLine] Available at http://www.visithadrianswall.co.uk/hadrianswall-country Accessed 03.09.2013

Loading

Halden, (2013)

Halden, D. (2013). Travel time and economic growth - Changing perspectives on travel choices for Scotland. In Scottish Transport Applications and Research Conference. 
Hall, 1999

C.M. Hall

Rethinking collaboration and partnership: A public policy perspective

Journal of Sustainable Tourism, 7 (1999), pp. 274-289

Loading

Hall, 2000

C.M. Hall

Rethinking collaboration and partnership: A public policy perspective

B. Bramwell, B. Lane (Eds.), Tourism collaboration and partnerships, Chanel View Publications, Clevedon (2000)

Loading

Hall, 2011

C.M. Hall

Policy learning and policy failure in sustainable tourism governance: From first- and second-order to third-order change?

Journal of Sustainable Tourism, 19 (2011), p. 649

Loading

Hall, 2004

D.R. Hall

Introduction

D.R. Hall (Ed.), Tourism, transformation and development, CABI Publishing, Cambridge, USA (2004)

Loading

Hill, (2013)

Hill, M. (2013). New look buses for X53 Jurassic Coaster. Dorset transport and travel [Online].

Available from: 〈http://www.dorset-transport.info/1/post/2013/07/new-look-buses-for-x53-

jurassic-coaster.html〉; Accessed 29.07.13.

Loading 
Hilland, 2011

S. Hilland

Funding for buses in tourist areas - the Black Forest and its KONUS guest card

In Funding Buses in Tourist Areas, University of Central Lancashire (2011)

Loading

Hong Kong Tourist Board, (2013)

Hong Kong Tourist Board (2013). Available at: 〈http://www.discoverhongkong.com/eng/plan-yourtrip/practicalities/transport/getting-around/mtr.jsp〉; Accessed 23.09.13.

Loading

Hoque et al., 2010

S. Hoque, P. Forsyth, L. Dwyer, R. Spurr, T. Van ho, D. Pambudi

The carbon footprint of Queensland tourism

Sustainable tourism, Queensland, Australia (2010)

Loading

Institute of Transport and Tourism, (2007)

Institute of Transport and Tourism (2007). Tourism on Board 2006. In J. Guiver (Ed.), University of Central Lancashire.

Loading

Intergovernmental Panel on Climate Change, (2007)

Intergovernmental Panel on Climate Change (2007). Climate change 2007: Synthesis Report.

Loading

Intergovernmental Panel on Climate Change, (2013)

Intergovernmental Panel on Climate Change (2013). Climate change 2013: The physical science basis.

Loading

Iseard, (2009) 
Iseard, N. (2009). Car-free holidays. The Observer, 26th April.

\section{Loading}

Jafari, 1987

J. Jafari

Tourism models: the sociocultural aspects

Tourism Management, 8 (1987), pp. 151-159

Loading

Jamal and Stronza, 2009

T. Jamal, A. Stronza

Collaboration theory and tourism practice in protected areas: Stakeholders, structuring and sustainability

Journal of Sustainable Tourism, 17 (2009), pp. 169-189

Loading

Jamal and Getz, 1995

T.B. Jamal, D. Getz

Collaboration theory and community tourism planning

Annals of Tourism Research, 22 (1995), pp. 186-204

Loading

Jones, 2010

Jones, E. (2010) Parking in Snowdon Unlocking the Green Key [OnLine] Available at

https://www.thebmc.co.uk/parking-in-snowdonia-unlocking-the-green-key Accessed 09.09.2013

Loading

Jones and Sloman, (2003)

Jones, P., \& Sloman, L. (2003). Encouraging behavioural change through marketing and management: What can be achieved. In 10th International Conference on Travel Behaviour Research (pp. 10-15). 
Kendal et al., 2011

J. Kendal, S. Ison, M. Enoch

UK National Parks: A role for road-pricing?

International Journal of Sustainable Transportation, 5 (2011), pp. 25-42

Loading

Kirkbride, (2011)

Kirkbride, A. (2011). RE: Interview. Type to J. Guiver.

Loading

Kirkbride, (2013)

Kirkbride, A. (2013). RE: Interview. Type to J. Guiver.

Loading

Kirkbride and Moore, (2009)

Kirkbride, A., \& Moore, J. (2009). Reconciling access, carbon and landscape impacts with creditcrunch economics. In Proceedings of the VisTrav Low Carbon Workshop.

Loading

Laing et al., 2009

J.H. Laing, D. Lee, S.A. Moore, A. Wegner, B. Weiler

Advancing conceptual understanding of partnerships between protected area agencies and the tourism industry: A postdisciplinary and multi-theoretical approach

Journal of Sustainable Tourism, 17 (2009), pp. 207-229

Loading

Lake District National Park Authority, 2013a

Lake District National Park Authority. 2013a. Visiting [Online]. Available at:

http://www.lakedistrict.gov.uk/visiting/thingstodo/cycling/electricbikes〉; Accessed 23.05.13. 
Lake District National Park Authority, 2013b

Lake District National Park Authority. 2013b. Electric Bikes [Online]. Available at: 〈 http://www.lakedistrict.gov.uk/visiting/thingstodo/cycling/electricbikes〉; Accessed 23.09.13.

Loading

Lake District National Park Authority \& Cumbria County Council, (2011)

Lake District National Park Authority \& Cumbria County Council (2011). Lake District Sustainable Visitor Transport Beacon Area. Department for Transport.

Loading

Lancashire County Council, (2013)

Lancashire County Council (2013). Silverdale Shuttle [Online]. Available at: 〈 http://www.lancashire.gov.uk/corporate/web/?Bus_Services/19923〉; Accessed 02.10.13.

R.D. Lasker, R. D., Weiss, E.S. and Miller, R. (2001) Partnership synergy: A practical framework for studying and strengthening the collaborative advantage, Milbank Quarterly, 79 (2001), pp. 179-205

Lew, A. and Mckercher, B. (2006) Modeling tourist movements: A local destination analysis, Annals of Tourism Research, 33 (2006), pp. 403-423

Lumsdon, L., \& Caffyn, A. (2012). Brecon Beacons and Powys Visitor Transport Plan. Brecon Beacons \{Halden, 2013 \#1177\}cons National Park Authority, Powys County Council.

Lumsdon, L., Downward, P. and Cope, A. (2004) Monitoring of cycle tourism on long distance trails: The North Sea Cycle Route, Journal of Transport Geography, 12 (2004), pp. 13-22

March, R. and Woodside, A.G. (2005) Testing theory of planned versus realized tourism behaviour, Annals of Tourism Research, 32 pp. 905-924

S.F. McCool, S. F. (2009) Constructing partnerships for protected area tourism planning in an era of change and messiness, Journal of Sustainable Tourism, 17 (2009), pp. 133-148

McLennan, C. L. L. Ruhanen, L., Ritchie, B. and Pham, T. (2012) Dynamics of destination development: Investigating the application of transformation theory, Journal of Hospitality \& Tourism Research, 36 (2012), pp. 164-190

Moody, E. (2004). RE: Interview for Hadrian's Wall Research. Communication to J. Guiver.

Moody, E. (2013). RE: Interview for current paper. Communication to J. Guiver.

Moritz, R.E., Bitz, C. and Steig, . E.J. (2002) Dynamics of recent climate change in the Arctic Science, 297 (2002), pp. 1497-1502

Morris, H. (2003). Hadrian's Wall Tourism Partnership. Tourisminsights.

Myswitzerland. (2012). Swiss travel system [Online]. Available at: 〈 http://www.swisstravelsystem.com/en/home.html〉; Accessed 24.09.13. 
National Geographic (2012). Eastern Newfoundland Geotourism MapGuide [Online]. Available at: http://www.nlgeotourism.com/content/cooks-lookout-trail/nfl1064137045790D07A〉; Accessed 23.09.13.

New Forest National Park (2013). Community routes [Online]. Available at: 〈 http://www.newforestnpa.gov.uk/info/20105/sustainability/292/community_routes〉.

Norfolk Green (2013). Coasthopper: Walks [Online]. Available at: 〈

http://www.coasthopper.co.uk/walks.aspx $;$; Accessed 12.10.13.

Northumberland National Park (2012). Tackling green transport challenges [Online]. Accessed 23.09.13.

Northumberland Tourist Information \& Northumberland Accommodation (2013). Northumberland National Park reports on Green transport activities [Online]. Available at: 〈

http://www.thisisnorthumberland.com/industry-news/northumberland-national-park-reports-ongreen-transport-activities/> [Accessed 23rd September 2013].

North York Moors National Park Authority (2013) Moorsbus

Nurture Lakeland. (2010). Fresh air is free [Online]. Available at:

http://www.nurturelakeland.org/archive-news/fresh-air-is-free.html〉; Accessed October 2012.

OECD (Organisation for Economic Co-operation and Development). (2012). OECD tourism trends and policies

Page, S. (1999) Transport and tourism, Addison Wesley Longman Ltd., Harlow, Essex

Peeters, P. and Schouten, F. (2006) Reducing the ecological footprint of inbound tourism and transport to Amsterdam, Journal of Sustainable Tourism, 14 (2006), pp. 157-171

Pembrokeshire Greenways (2012). Walking Pembrkeshire [Online]. Available at: (http://www.pembrokeshiregreenways.co.uk/〉; Accessed 23.09.13.

Pike, S. (2013) Destination marketing and management - Theories and applications, Tourism Management, 34 (2013), pp. 247-248

Proctor, K. (2011). Cutting rural Cumbria buses 'a blow for elderly'. Westmorland Gazette.

Public Transport Victoria (2013). myki Visitor Pack [Online]. Available at: 〈 http://ptv.vic.gov.au/tickets/myki/myki-visitor-pack/> ; Accessed 23.09.13.

Reeves, R. (2006). Tackling traffic. Council for National Parks.

Reghage, J. (2010). Towards a greater international competitiveness of cross-border destinations: Internal strategic organisational destination management criteria for future success. Master of Tourism Destination Mangement, NHTV Breda University of Applied Sciences,.

Richardson, H. and Nichols, C. (2004) Purbeck Transportation Study. Dorset County Council, Buro Happold Ltd (2004)

Robbins, D. and Dickinson, J. (2008) Transport to visitor attractions A. Fyall (Ed.), Managing visitor attractions, Butterworth-Heinemann, Oxford (2008)

Roberts, O. 2013. RE: Interview for current paper. communication to J. Guiver. 
Roberts, O. \& Rees, S. (2012). Pembrokeshire Greenways. Promoting Pembrokeshire...On The Move! Stackpole, Pembrokeshire.

Romeril, M. (1985) Tourism and conservation in the Channel Islands, Tourism Management, 6 (1985), pp. 43-49

Royce, K. (2002). How to create a successful visitor payback scheme. In L. Davies (Ed.), Visitor payback schemes: Countryside recreation network.

Ruoff, J. (2012). RE: Konus Card Interview. Communication to J. Guiver.

Rye, T. (2002) Travel plans: Do they work? Transport Policy, 9 (2002), pp. 287-298

Scott, A., Christie,M. and Tench H. (2003) Visitor payback: Panacea or Pandora's box for conservation in the UK? Journal of Environmental Planning and Management, 46 (2003), pp. 583-604

Scottish Enterprise (2012). New co-operative puts Scotland's hidden tourism gem on the map. Scottish Enterprise, 29th June.

Selin, S. and Chavez, D. (1995) Developing an evolutionary tourism partnership model, Annals of Tourism Research, 22 (1995), pp. 844-856

R. Sharpley, J. Sharpley (1999) Rural tourism: An introduction, Thompson Business Press, London Shropshire Hills Area of Outstanding Natural Beauty. (2013). Shropshire Hills shuttle buses [Online]. Available at:〈http://www.shropshirehillsaonb.co.uk/things-to-do/shuttles/〉; Accessed 18.10.13.

Simpson, M. C., Gössling, S. Scott, C., Hall, C.M. and Gladin, E. (2008) Climate change adaptation and mitigation in the tourism sector: Frameworks tools and practices, UNEP, University of Oxford, Paris, France

Small World Consulting Ltd (2010). A carbon budget for the Lake District National Park.

Small World Consulting Ltd (2012). 2008 Consumption-based greenhouse gas footprint of Cornwall and the Isles of Scilly. Lancaster University.

South Downs National Park Authority \& New Forest National Park Authority (2012). Sustainable Transport Solutions for England's two newest National Parks (p. 29).

Speakman, C. (2011). RE: Interview for Seasonal Buses. Personal communication to J. Guiver.

Speakman, C. \& Transport for Leisure Ltd (2008a). Visitor travel plans for countryside leisure destinations. Natural England.

Speakman, C. \& Transport for Leisure Ltd (2008b). Good practice in sustainable leisure travel: Twenty case studies. Natural England.

Stanford, D. (2008) 'Exceptional visitors': Dimensions of tourist responsibility in the context of New Zealand, Journal of Sustainable Tourism, 16 (2008), pp. 258-275

Stanford, D. (2013) Reducing visitor car use in a protected area: A market segmentation approach to achieving behaviour change

Journal of Sustainable Tourism, 21 (2013) 
Stanford, D., Carter, R., \& George, C. (in press). Destination management for the green economy. In M. Jiang, T. Delacy, G. Lipman, S. Vorster, \& R. Hawkins (Eds.), Green growth and travelism: The academic viewpoint. Oxford: Routledge.

Sustrans (2013) Connect2 Greenways Guide http://www.sustrans.org.uk/ourservices/infrastructure/route-design-resources/documents-and-drawings/key-reference-documents0 accessed 09.09.2013

Thimm, T. (2012). Governance structures for sustainable tourism mobility in the Lake Constance region. In Psychological and behavioural approaches to understanding and governing sustainable tourism mobility.

Transport for London (2013). Visitor tickets [Online]; Accessed 23.09.13.

United Nations Environment Programme and World Tourism Organization (2012), Tourism in the Green Economy - Background Report, UNWTO, Madrid. [OnLine] Available at http://www.unep.org/greeneconomy/Portals/88/documents/ger/ger_final_dec_2011/Tourism\%20i n\%20the\%20green_economy\%20unwto_unep.pdf Accessed 03.09.2013

United Nations World Tourism Organization (2007). Tourism \& climate change: Confronting the common challenges.

Visit Sefton and West Lancashire (2013). Themed cycling routes in Sefton [Online]. Available at: < http://www.visitseftonandwestlancs.co.uk/days-without-the-car/cycling-routes/themed-cyclingroutes-in-sefton.aspx $\rangle$.

VisitEngland (2008). Destination manager's toolkit: Sustainable visitor transport. VisitEngland.

VisitOlso (2013). Available at: 〈http://www.visitoslo.com/en/activities-and-attractions/oslo-pass/ $>$; Accessed 23.09.13.

Y. Wang, Z. Xiang (2007) Toward a theoretical framework of collaborative destination marketing Journal of Travel Research, 46 (2007), pp. 75-85

Warren, N. (2010). Sustainable tourism travel-Are we nearly there yet?

White, S. (2011) Guidance note two: Local economic impact modelling approaches In Measuring tourism locally, Office for National Statistics, London (2010)

Wibmer, C. (2012). Where public transport runs on GUTi: GUTi Gasteservice Umwelt-Ticket GuestService-Ticket for sustainable environment. In Association of European Transport Conference.

Wood, C. (2009). Green access for countryside recreation. Norwich: Widen the choice. East of England Development Agency.

World Economic Forum (2009). The travel \& tourism competitiveness report 2009: Managing in a time of turbulence.

Wray, M. (2011) Adopting and implementing a transactive approach to sustainable tourism planning: Translating theory into practice Journal of Sustainable Tourism, 19 (2011), pp. 605-627 
Zürich. 2013. ZürichCard [Online]. Available at: 〈http://www.zuerich.com/en/Visitor/zuerichcard.html〉; Accessed 09.092013.

Loading

Corresponding author. Tel.: +44 1772 894923; fax: +44 17728929271.

Tel.: +4401138125521. 